Article

\title{
Comparison as Conversation and Craft
}

\author{
Kathryn McClymond \\ Department of Religious Studies, Georgia State University, 25 Park Place, Suite 1700, Atlanta, GA 30302-4089, \\ USA; kmcclymond@gsu.edu
}

Received: 15 January 2018; Accepted: 26 January 2018; Published: 30 January 2018

\begin{abstract}
This essay argues that comparison as a method of study within religious studies is best thought of in two terms: conversation and craft. As a conversation, comparison has its own history, which has included several major shifts. At present, comparative work would benefit from addressing the fact that Euro-Americans dominate the comparative conversation. This dominance limits conversational data, topics, strategies, and participants. At risk is the relevance of comparative work within religious studies. As a craft, comparative work is creative and idiosyncratic, reflecting the apprenticeship lineage in which the comparative scholar has been trained as well as her individual personality.
\end{abstract}

Keywords: comparison; conversation; craft; method; Euro-American

I have been engaged in comparative research for over twenty years now. It is always tricky when comparison itself becomes the object of study, rather than the mode of study. This is particularly true of comparative work, because it transgresses traditional boundaries of study, creating new research contours. Seemingly disparate religious phenomena become bedfellows. Over the years, I have found this approach to the study of religion simultaneously challenging, uplifting, dangerous, and enlivening.

This edited volume offers an opportunity for me to reflect on what I do and how I do it. I started by thinking about the line I always share with my students: "comparison isn't a conclusion; it's a method." I will continue to teach this mantra, because it highlights comparison as process rather than end goal. Over the years, though, I have come to feel that the term "method" is too clinical-my research process is much messier than the term suggests. As I have struggled to express my research process is really like, two words bubbled to the surface: conversation and craft. Throughout the rest of this essay, I hope to explain how I engage in comparison as an ongoing conversation, with shifting topics, trajectories, and partners, but always grounded in a community-wide exchange of ideas. I will also argue that comparison is best imagined as a craft, which involves long apprenticeships, training in specific skills, yielding unique products bearing the stamp of their makers.

\section{Comparison as Conversation}

In the Department of Religious Studies at Georgia State University, we are famous for asking our graduate students to identify consciously the audience to whom they are directing their research. My colleague Jonathan Herman asks virtually every prospective thesis writer, "Who are you talking to? Which existing intellectual conversation are you joining? Who do you want to read your work?" While the process of writing is often a solitary exercise, the scholar's task is to make her intellectual thoughts public, to inject an ongoing conversation with new ideas. We are expected to generate original insights, but not in a vacuum. The strongest scholarship situates itself in ongoing lineages of thought while opening up new trajectories for future study. These ongoing lines of thought (sometimes spanning generations) differ from topic to topic and subfield to subfield. Scholars must become familiar not only with the scholarly literature on certain bodies of data (e.g., sacrificial practices in certain traditions), but also with the different interpretive approaches used to make sense of the data 
(e.g., textual, historical, anthropological) and key figures who have shaped the field (e.g., Henri Hubert, Marcel Mauss, Nancy Jay, René Girard).

Those of us who engage in comparative work join a distinctive ongoing conversation, which has its own history. As Oliver Freiberger has discussed, much of the last fifty years has been a reaction to "macro-comparative studies, especially approaches in the phenomenology of religion (classical examples are van der Leeuw 1967; Eliade 1958; Heiler 1961) that were partly responsible for the bad reputation that comparison gained in the second half of the twentieth century." ${ }^{1}$ The strongest critiques charged that comparative projects such as those offered by Eliade emphasized similarity between cultural elements, with little regard for real phenomenological differences or for social and historical context, and often characterized specific symbols or myths in simplistic and distorted ways to force a similarity that, upon closer examination, doesn't really exist.

My generation of scholars came of age at a time when Jonathan Z. Smith challenged this approach to comparativism and took the conversation in a new direction. Like many students of religion, I was shaped by his essay "In Search of Place," included as a chapter in To Take Place. In this essay, Smith takes Mircea Eliade to task for his interpretation of the Tjilpa sacred pole as an "axis mundi." However, Smith does not reject comparison completely as a method. Instead, he argues that comparative work must be marked by certain elements:

It is axiomatic that comparison is never a matter of identity. Comparison requires the acceptance of difference as the grounds of its being interesting, and a methodical manipulation of that difference to achieve some stated cognitive end. The questions of comparison are questions of judgment with respect to difference. What differences are to be maintained in the interests of comparative inquiry? What differences can be defensibly relaxed and relativized in light of the intellectual tasks at hand? ${ }^{2}$

Smith's critique of Eliade shaped an entire generation of scholars to follow, launching the next phase in a conversation about comparative method. This phase emphasized careful linguistic, textual, and historical study. In effect, he launched a new comparative conversation, one that eschewed superficial similarities and emphasized nuanced readings of data and narrow conclusions. In so doing, Smith became the voice of comparative work in the last third of the twentieth century. After Smith, any respectable contribution to the comparative conversation had to reflect a deep understanding of language and history, as well as facility with mythological tropes.

As we moved into the twenty-first century, a new generation of comparativists rose to prominence. In 2000, Kimberley C. Patton and Benjamin C. Ray published A Magic Still Dwells, an edited volume built on two panels presented at the American Academy of Religions and including well-recognized comparativist scholars. The original panel sessions and the subsequent edited volume self-consciously assessed the work of comparative religious studies approximately twenty years after Smith's groundbreaking "In Comparison A Magic Dwells," included in his volume (Smith 1982). While Smith had originally focused on challenging universalizing tendencies in comparative work, A Magic Still Dwells focused on comparativism in the postmodern age. Specifically, Patton and Ray claim, "this volume seeks to demonstrate that a broader vision of religion, involving different scales of comparison for different purposes, is both justifiable and necessary." ${ }^{3}$ In this volume, the authors take on the postmodern critique writ large, many of them seeing the roots of this critique in Smith's own work. Patton and Ray "reclaim" the word "magic," a term that signals their belief that "comparison is an indeterminate scholarly procedure that is best undertaken as an intellectually creative enterprise, not as a science but as an art-an imaginative and critical act of mediation and redescription in

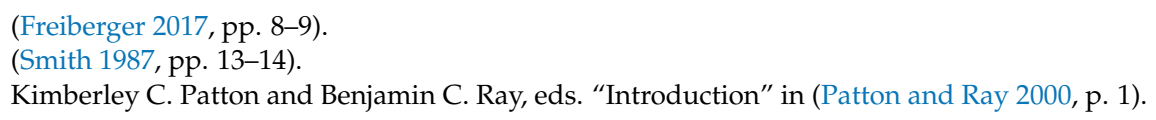


the service of knowledge." ${ }^{4}$ They refer to "playing across the 'gap' of differences, for the purpose of gaining intellectual insight." ${ }^{\prime 5}$ Comparison in this volume is characterized as a kind of "bridge" strategy, dynamically negotiating between a specific question developed for a specific conversation and audience, and the conclusions that ends the conversational thread.

So where are we now, almost twenty years after A Magic Still Dwells? What is the intellectual context in which comparativists do their work? What is the next turn that comparative conversations must take? My strong feeling is that the comparative enterprise must take seriously the constructive quality of a comparative conversation. We are all aware that the very act of comparison creates a relationship between comparands that may not exist in any other context. For the sake of addressing an intellectual question, specific cultural elements are brought into relationship with one another. Thoughtful comparativists are very careful about articulating the limited nature and scope of that relationship. However, virtually no attention has been paid to the relationship that is constructed between comparativist conversation partners. In the very act of comparing, some individuals and communities are included and others are not. This inclusion and exclusion reflects and instantiates power dynamics between scholars, including certain voices while excluding others. This inevitably affects the comparative scholarship that results.

Throughout my career, I have joined other scholars arguing that our comparative conversations are skewed because the terms we use reflect a Christian (specifically Protestant) understanding of and taxonomy for religious thought and practice. Barbara Holdrege, in her landmark comparative work Veda and Torah, uses a careful examination of the Vedas and Torah to demonstrate how including non-Christian forms of "scripture" explodes the category. ${ }^{6}$ In my own comparative work I have argued that sacrifice in the Vedic and Jewish traditions do not have the connotation of violence that Protestant Christian sacrifice does—-thus, "sacrifice" should not universally be characterized as violent.

I would like to be able to say that comparative scholarship has evolved beyond the privileging of Protestant Christianity since Holdrege launched comparative Hindu and Judaic studies to challenge Christian paradigms that shape the academy - but I can't. At a recent gathering of scholars dedicated to comparativism, a couple of us who specialize in non-Christian traditions suggested to a colleague that we broaden the research terms that we regularly interrogate (e.g., law) to include non-English terms that are important in non-Christian traditions (e.g., dharma). Our point was that in limiting the terms to English terms that often grow out of Protestant Christianity or scholarship grounded in Christianity, we automatically "other" non-Christian, non-Western (and non-English based) traditions. The two of us were taken aback when our colleague protested, arguing that dharma does not make sense in any tradition other than Hinduism, so why would we propose launching a comparative conversation with a term that was not going to be of general interest to everyone in the room? And why propose a term that scholars who did not specialize in Hinduism could not engage? This colleague did not seem to understand how we, as scholars of non-Christian traditions, might feel marginalized by conversations that were grounded in a term that has to be translated into the traditions we study (never mind our Indian colleagues communities who actually practice these traditions). Even among thoughtful comparativists, the tendency is to imagine that certain terms are more universal than others.

Moving forward, we need to remind ourselves that the comparative conversation itself is historically and culturally situated. Comparative work lays bare dynamics that underlie the study of religion more broadly. Who is included? Who is not? Who establishes the categories that shape how data is selected and framed? However, if done correctly, comparative work can also drive constructive change within the academy, precisely because comparison draws attention to differences between conversations, not only in their content, but also in their very structure. Conversations historically

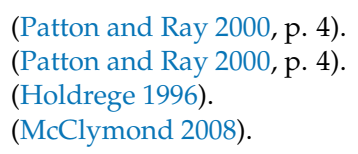


focused on "law" are forced to reflect on the significance of choosing "law" as a category in contrast to dharma.

But the problem goes deeper. My concern is that the current comparative conversation still participates in unequal treatment and inclusion of certainly scholarly conversations and voices. The comparative enterprise has roots in Euro-American colonialism. Historically, this has resulted in the objectification of other communities. My concern is that this dynamic persists, albeit unintentionally, in how conversations are conducted today. Conference sessions and publications are dominated by Euro-American participants. The present volume originated in an American Academy of Religion panel session, and all the panelists were Euro-American (as was the vast majority of the audience). A cursory review of other conferences, monographs, and edited volumes suggests that this is the norm. At its most benign, this suggests that the comparative conversation as it is currently conducted does not speak to non-Euro-American scholars and audiences. Put more negatively, today's comparative project may be off-putting to our colleagues who come from and/or conduct research focused on underrepresented groups, especially African-American traditions, Native American communities, and certain Asian and Middle Eastern groups. At its worst, the unequal participation in comparative conversations results in the silencing of important voices. Sociologist Daniel Everett notes, "The majority ... forms more than a cultural enclave. It is the enveloping culture that can muffle other voices in norms of comfortable discourse, routines of diet, and too much sameness in social and cultural experiences." 8

The traditional understanding of comparativist work-the so-called "objective" approach of laying one community's religious thought and practice alongside another community's practice-ignores the very real ways in which centuries of oppression play out in comparative research. This is, to some extent, understandable. Those of us who self-consciously trained in comparison followed a traditional path, described by Patton and Ray: "the authors of these [comparative] essays, unlike most of their theological predecessors in the comparative study of religion, were trained as area studies specialists. Their work is shaped by immersion in primary texts, by interdisciplinary conversation with area studies specialists, and by collaboration with members of other religious communities." ${ }^{\prime 9}$ This training privileges certain data (e.g., texts), certain training (e.g., individualized training in textual analysis, archival work, and languages), and certain experience (e.g., extended travel to specific geographic areas). This training shapes what will be studied (e.g., text-based traditions) and who is qualified to engage in that study (scholars who have spent an extended period in graduate school, often including time overseas). Looking forward, I believe comparative work has to be more cognizant of its moral component. Ray argues,

I would propose that the purpose of comparative religion is both intellectually heuristic and morally engaged. It is based upon intellectual and moral involvement with religious communities (past or present) and with the community of scholars who study them. Its aim is not to identify transcendent universals but to discover enriching insights into shared aspects of human experience, and thus to advance the conversation of humankind. Insights gained through comparison should enable people of different cultures and religions to enter into dialogue, to gain mutual understanding, and to build important religious bridges and political relationships. ${ }^{10}$

In order to accomplish the goals Ray outlines above, those of us currently included in the comparative project need to acknowledge that our current conversation does not include a wide range of partners. As a starting point, the current comparative scholarly community needs to own its history and tackle it head-on. Those of us who enjoy privilege need to think how this privilege has allowed us

\footnotetext{
(Everett 2017, p. B7).

(Patton and Ray 2000, p. 12).

10 Ray, “Discourse about Difference" in (Patton and Ray 2000, pp. 115-16).
} 
to shape comparative conversations without explicitly normative dimensions. I suspect that this is because we don't see the normativity already embedded in our work.

I make this argument for the sake of comparative scholarship itself. Comparative conversations conducted virtually entirely by Euro-American scholars will become increasingly irrelevant (at best). Everett concludes his plea to "seek out strangers" by noting, "It is the majority that is at the greatest danger of missing the power of diversity." 11 Fortunately, scholars in the comparative community have a history of reimagining the work to address past methodological errors. Each new phase of the conversation has been launched to generate rigorous intellectual inquiry. Self-conscious efforts to include more diverse conversation partners will inevitably shed light on missteps and missed opportunities in past scholarship. Stated in the affirmative, intentionally recruiting scholars who focus on and come from socially, politically, and economically underrepresented communities into the comparative enterprise will enrich our scholarship.

\section{Comparison as Craft}

In addition to imagining comparison as a conversation, I imagine comparative work as a craft. I take this term from Ronald Grimes's 2014 work The Craft of Ritual Studies, in which he argues that ritual studies is a "craft": "Craft is art's practical-minded, hands-on, manual-laborer cousin."12 Grimes explains, "To treat ritual studies as a manual art, an activity of the hands, arises from a conviction that theorizing, like ritualizing, is inescapably embodied." 13 He concludes by paraphrasing the Roman writer Terence: "I study ritual because nothing human ought to be foreign to me."14 My own paraphrase would be, "I study comparatively because nothing human ought to be foreign to me." I see this as a fundamentally optimistic approach toward the study of human culture. It assumes that no human cultural expression is so foreign as to be completely unintelligible. This does not mean that I believe we can ever enjoy complete or perfect understanding. But comparative work is dynamic, ongoing, and accumulative. Over time, imperfect understanding yields to slightly improved imperfect understanding. More audaciously, I assume that differing human experiences and expressions can be brought into conversation with one another in meaningful ways that yield insight into human religious thought and practice.

To make such a claim is to take a very particular stance toward the data we scholars of religion study. However, this is just the beginning; the "hands-on" labor that Grimes refers to has not yet begun. This is where the linguistic, historical, ethnographic, and analytical skills learned over long years in the academy are put to the test. Ours is an apprenticeship profession, and we are trained as skilled workers. If we are lucky, we get to train with master craftsmen and craftswomen, watching over their shoulders (sometimes literally) to see how they select the material they will work with, how they play with it, and how they bring the tools they have been trained to use to bear upon the "stuff" of religion. There is no single, correct method, although certain practices are common.

I suspect that my general approach to the craft of comparison is fairly typical in its broad contours, so I will describe the approach I took for my most recent book, Ritual Gone Wrong (2016), as a case in point. ${ }^{15}$ Years ago, while I was completing graduate level coursework, I learned the story of Tvastr, a Vedic god. According to one myth, Tvastr mispronounces a mantra when creating the demon Vrtra. Because of the mispronunciation, Vrtra does not slay Indra (as intended); instead Vrtra is slain by Indra-a big difference. What struck me was the fact that it did not matter what Tvastr intended when he spoke, but what he actually said. The ritual went wrong, and it could not be fixed. Suddenly I became interested in acts that did not go as planned.

\footnotetext{
(Everett 2017, p. B27).

(Grimes 2014, p. 4).

(Grimes 2014, p. 5).

(Grimes 2014, p. 5).

(McClymond 2016)
} 
As I was mulling over the Tvastr story, I remembered the biblical story of Isaac blessing Jacob when he should have blessed Esau. As you may remember, the Bible says, "Isaac was old and his eyes were dim" (Gen. 27:1). Rebekah, Jacob's mother, encourages Jacob to trick his father into giving him the blessing intended for the eldest son. When Isaac realizes he has blessed Jacob instead of Esau, he declares, "Your brother came deceitfully, and he has taken away your blessing" (Gen. 27:35). Again, there is nothing Isaac can do, and the fact that he intended to bless Esau rather than Isaac doesn't matter. The blessing went wrong.

At first blush, these two stories struck me as similar, and thus my comparative thinking began. However, as I reread the stories I noticed a key difference: Tvastr mispronounced a mantra-the actual words he spoke were incorrect. Isaac's problem was not his wording, but the object of the blessing. Each actor mis-performed a verbal act, but in different ways. Rituals had gone wrong, but in different ways.

For various reasons, my research headed in other directions and I tucked these two stories away in my head, where they stayed for almost fifteen years. During that time I dove deeply into Vedic ritual texts and the Mishnah, and I realized that Vedic and rabbinic literature includes vast quantities of material talking about ritual mistakes: what could go wrong, what could be fixed, what the consequences were if mistakes were not (or could not be) fixed, etc. At the same time, I was steeped in ritual theory: Roy Rappaport, Catherine Bell, Clifford Geertz, Jonathan Z. Smith, Ronald L. Grimes, Mary Douglas, Victor Turner, Stanley J. Tambiah-you name it, I read it. And something else struck me: ritual theorists never incorporated ritual mistakes or disruptions of any kind in their theorizing. Ritual mistakes were acknowledged, of course, but the fact that many ritual systems include robust mechanisms for addressing and complex philosophies for making sense of ritual mis-performances was never systematically incorporated into ritual theorizing. Fondly, I remembered Tvastr and Isaac, and I was off to the races.

I tell this story to demonstrate how unmethodical this project seemed to be in the early phases. As I think back on it, however, much of what I did in the generative stages of this project grew out of my training. I began with data, and I steeped myself in the data. When I became interested in the Tvastr and Isaac stories, I read them in the original Sanskrit and Hebrew, I noted their literary contexts, and I studied the contexts in which these stories probably originated and were collected. I spent two decades becoming familiar with the ritual (especially sacrificial) literature in the Mishnah and the Vedic śrautasūtras (solemn ritual manuals). I steeped myself in ritual theory. When I decided to take up the ritual gone wrong project, I researched as many cases of ritual disruption as I could. I played with the terms "mistake," "error," "mis-performance," and many others, trying to determine which term captured the full range of ritual mis-activity I had encountered, and settled on "disruption."16

While in the throes of researching, I moved back and forth from example to theory, example to theory, as I began to formulate my own thinking about ritual disruption as an important element of ritual theorizing. Once my own thinking was beginning to crystallize, I spent more and more time in theory, looking primarily for challenges to my initial ideas. Once I was fairly secure in what I wanted to present, I reviewed the examples that had been the basis of my research, and selected several to develop fully as case studies for my reader. From that point on, the focus was on writing to communicate clearly with a reader.

I wish I could say that I was self-conscious and intentional about my approach from beginning to end during this project, or that I had a clear method in mind as I began. Honestly, however, that's not what happened. As I think back on my process, however, I can point to constant engagement with data. I engaged this data using textual, historical, and comparative methods in which I am trained. Finally, I infused my thinking with theoretical approaches from a wide variety of ritual theorists throughout the entire project. Data, method, and theory were in constant conversation with one another. Again,

16 The term "disruption" emerged in one of several rich conversations with Laurie L. Patton. I am grateful for this conversation and many others over the years that have enriched my thinking. 
here my approach resonates with Grimes, who characterizes his own work as moving from method to case to theory, with the understanding that these three elements "play off each other. Their relationship is circular and interactive rather than linear or hierarchical."17

Here my process differs from what Oliver Freiberger prescribes in the essay he contributes to this volume. Freiberger argues that comparison is be best employed as a "second order method," that is, as a tool one uses to enter a particular conversation, to follow a particular line of questioning that can only be developed once a basic understanding of data has occurred. My own experience is that understanding occurred virtually simultaneously with a comparative act. As I understood the significance of Tvastr's mispronunciation, I virtually simultaneously thought of the biblical story concerning Isaac's blessing. And it is only because I held two examples of verbal mis-performances in my head simultaneously that a particular research questions formulated in my thinking. The comparison generated a question that most likely would not have sprung from one example on its own.

Having said that, I do agree with Freiberger that during the work of comparison, one must dig deeply into the primary data very early on to confirm that comparison is warranted. Comparative conclusions can only be explored fully after some basic work of understanding has been completed. Of course, this is a dynamic process. Investigation necessitates further and new understanding which in turns shapes further investigation.

Certain guidelines do inform my "craftsmanship." As a comparativist, I am constantly aware of bringing data from distinct contexts into conversation with one another. I constantly ask myself whether area studies scholars who know the material I include in my comparative work would be comfortable with my characterization of the data. Is my description of Isaac's blessing above something that biblical scholars would say is accurate? Is my brief summary of Tvastr's mispronunciation such that scholars of Hindu mythology would be comfortable? Do I include misstatements or exclude critical "backstory" material? These are important questions for me to answer not only as I am conducting my research and formulating my own analysis, but as I write for a comparative audience. Would my area studies colleagues sign off on my description?

Beyond that, once I begin my comparative work, I simply accept the fact that some area studies folks will not be happy. Ritual Gone Wrong includes chapters on passages in the Baudhāyana śrautasūtra; discussion of passages in the Mishnah; an analysis of opening and victory ceremonies in several Olympic Games; and an interpretation of Saddam Hussain's trial and execution. (Ironically, Tvastr and Isaac are nowhere to be found.) The act of laying these topics alongside one another, in and of itself, will give some of my colleagues pause before they have read a single word. I am comfortable with that because I trust that my own close textual and historical research have laid the groundwork for valid, meaningful comparison.

Just as importantly, I am comfortable with laying these topics alongside one another because the research question I am exploring - what does ritual disruption contribute to our thinking about the nature of ritual?-warrants comparative work. Kimberly C. Patton, in her brilliant monograph Religion of the Gods, makes the case for comparative research in her own project when she determines "that it is virtually impossible to solve the hermeneutical problem of the 'libating gods' in ancient Greek vase painting by staying within the evidence afforded by the tradition. One needs to look elsewhere, and to subject these images to the multiple recombination afforded only through comparative analysis."18 Similarly, I believe that comparison is justified (and should be celebrated) when a research question simply cannot be adequately addressed by examining a single body of data. The scholar alone determines this.

One final observation about the comparative study of religion as "craft." Each comparative exercise is unique, bearing the fingerprint of the scholar behind the work. Just as craftspeople

17 (Grimes 2014, p. 3).

18 (Patton 2009, p. 9). 
have distinctive styles-you would never confuse a Noguchi table with one created by Frank Lloyd Wright—individual comparativists work in idiosyncratic ways. You would never confuse Barbara Holdrege's work with Jonathan Z. Smith's. This is not to say that there is no method or discipline in their work, but rather to say that we all do the work of studying humans in a personal way.

\section{Conclusions}

A few closing thoughts on how to understand the fruit of our conversation and craftsmanship. The act of comparing is intentional and self-conscious. It requires a deliberate choice to engage specific data in a specific way-one chooses to place $X$ beside $Y$. For me, the deliberate, self-conscious nature of comparison is a healthy reminder that all academic study involves the creation of intellectual data out of raw human experience, thought, and practice. It's the highest form of alchemy. In articulating, resituating, and interpreting human experience we actually create something that did not exist previously, often renaming phenomena and establishing new relationships that defy space and time. In the act of comparison, scholars create new bodies of knowledge and, perhaps more significantly, new relationships between bodies of knowledge, generating new frameworks and paradigms for making sense of human experience. These new bodies of knowledge do not come into being ex nihilo; rather, we take straw and turn it into gold. (And occasionally, we manage to turn gold into straw.)

One benefit of understanding the craft of comparison in this way is that it stops us from imagining that what we produce is "real" in any ontological sense. The knowledge we create is not, in fact, religion. It is the product of the comparative scholar's imagination. This is not to say that comparative work cannot lead to deep profound insights. Rich creative work-whether artistic or academic — can lead to a deep understanding of human experience. But the kind of truth that grows out of creative work should never be confused with the human experience itself.

Finally, whatever insights comparative work yields will be imperfect. This is true of all scholarship, but comparative work will always suffer from that fact that at some level, it always involves an act of translation. When I lay phenomenon A beside phenomenon B, I am forced to use language to describe at least one of them in a foreign language of sorts. For example, when I compare the Vedic paśubandha (bound animal offering) with the biblical zębāhîm (slain offerings), there are no common terms. I use the term "sacrifice" to encompass them both —an act of translation (as well as classification). In attempting to talk across two traditions, I generate a third language, the comparative dialect, which uses a term foreign to both the Vedic and biblical authors. I believe that this move leads to understanding of the broader notion "sacrifice," but it is inevitably incomplete and, to some extent, distorted. Comparison will never be free from this translational impediment. Nevertheless, even with this limitation in mind, I am persuaded that diligent and thoughtful comparative work leads to insights that will not arise in any other academic conversation.

To elect to become a comparativist, to participate in a flawed conversation, to accept that a lifetime of training will still yield an imperfect result, is daunting and, at times, discouraging. Why would anyone choose such a profession? I take inspiration from perhaps an unexpected source: J.K. Rowling. In her Harvard University Commencement address, Rowling notes, “Unlike any other creature on this planet, humans can learn and understand, without having experienced. They can think themselves into other people's places." ${ }^{19}$ The comparativist not only thinks herself into other people's places; she dares to place people from completely disparate places into conversation with one another-and then to explain the significance of that imagined conversation to willing listeners. I cannot imagine a worthier effort in today's world.

Conflicts of Interest: The author declares no conflict of interest.

19 J.K. Rowling presented the original version of this address at Harvard University on 5 June 2008. The published version appears in (Rowling 2008, p. 56). 


\section{References}

Everett, Daniel. 2017. Seek out strangers. The Chronicle Review 63: B5-B7.

Freiberger, Oliver. 2017. Elements of a Comparative Methodology in the Study of Religion. Paper presented at the American Academy of Religion Annual Conference, San Antonio, TX, USA, November 18-21.

Grimes, Ronald L. 2014. The Craft of Ritual Studies. Oxford: Oxford University Press.

Holdrege, Barbara A. 1996. Veda and Torah: Transcending the Textuality of Scripture. Albany: SUNY Press.

McClymond, Kathryn. 2008. Beyond Sacred Violence: A Comparative Study of Sacrifice. Baltimore: Johns Hopkins University Press.

McClymond, Kathryn. 2016. Ritual Gone Wrong: What We Learn From Ritual Disruption. Oxford: Oxford University Press.

Patton, Kimberley C. 2009. Religion of the Gods: Ritual, Paradox, and Reflexivity. Oxford: Oxford University Press.

Kimberley C. Patton, and Benjamin C. Ray, eds. 2000. A Magic Still Dwells: Comparative Religion in the Postmodern Age. Berkeley: University of California Press.

Rowling, Joanne Kathleen. 2008. Very Good Lives: The Fringe Benefits of Failure and the Importance of Imagination. Boston: Little, Brown and Company.

Smith, Jonathan Z. 1982. Imagining Religion: From Babylon to Jonestown. Chicago: University of Chicago Press. Smith, Jonathan Z. 1987. To Take Place: Toward Theory in Ritual. Chicago: University of Chicago Press.

(C) 2018 by the author. Licensee MDPI, Basel, Switzerland. This article is an open access article distributed under the terms and conditions of the Creative Commons Attribution (CC BY) license (http://creativecommons.org/licenses/by/4.0/). 